\title{
PENGEMBANGAN BAHAN AJAR ELEKTRONIK BERBASIS MODEL PROBLEM BASED LEARNING DENGAN MENGGUNAKAN MODEL DICK AND CAREY
}

\author{
Wilfridus Muga, \\ STKIP Citra Bakti, NTT \\ faneza27m@citrabakti.ac.id
}

Bayu Suryono

STKIP Citra Bakti, NTT

bayu.suryono@gmail.com

Eko Lodang Januarisca

STKIP Citra Bakti, NTT

\begin{abstract}
Abstrak
Tujuan dalam penelitian ini adalah 1) menghasilkan bahan ajar elektronik matakuliah strategi pembelajaran berbasis problem based learning dengan menggunakan model Dick and Carey, dan 2) mendeskripsikan kualitas hasil uji coba produk pengembangan bahan ajar matakuliah strategi pembelajaran berbasis problem based learning dengan menggunakan model Dick and Carey. Penelitian ini dilakukan di Kabupaten Ngada Provinsi Nusa Tenggara Timur. Subjek dalam penelitian ini adalah kurikulum matakuliah strategi pembelajaran serta pakar dan mahasiswa di STKIP Citra Bakti. Sedangkan objek yang diteliti adalah bahan ajar elektronik matakuliah strategi pembelajaran berbasis model problem based learning. Model pengembangan yang digunakan dalam pengembangan bahan ajar matakuliah strategi pembelajaran ini adalah model Dick \& Carey. Hasil pengembangan kemudian dianalisis secara deskriptif. Hasil pengembangan memperlihatkan bahwa buku ajar elektronik dapat dibuat dan dikembangkan. Hasil uji ahli buku ajar elektronik yang dikembangkan dapat diketahui bahwa buku ajar elektronik yang dikembangkan menurut pada ahli ada pada kategori "sangat baik". Sedangkan hasil uji perorangan buku ajar elektronik yang dikembangkan dapat diketahui bahwa buku ajar elektronik yang dikembangkan berdasarkan tanggapan mahasiswa, ada pada kategori "sangat baik". Aspek yang paling tinggi menurut tanggapan mahasiswa adalah tampilan buku ajar yang dikembangkan.
\end{abstract}

Kata-kata kunci: bahan ajar elektronik, problem based learning, model Dick and Carey

\begin{abstract}
The aimed of this research are: 1) to produced electronic materials of Strategi Pembelajaran (Strategy of Instruction) based on problem based learning using Dick and Carey model, and 2) to described the quality of electronic material has been development. This research was conducted in Ngada Regency of East Nusa Tenggara Province. Subjects in this study is the curriculum of learning strategy course as well as experts and students in STKIP Citra Bakti. While the object under study is the instructional material of learning subject-based learning model based on learning model. The development model used in the development of learning subject matter of this learning strategy is Dick \& Carey model. The results of the development are then analyzed descriptively. Development results show that electronic textbooks can be created and developed. Experimental test results of electronic textbooks developed can be seen that the electronic textbook developed according to the expert is in the category of "very good". While the results of individual electronic textbook test developed that it can be seen that electronic textbooks developed based on student responses, there in the category of "very good". The highest aspect according to student responses is the textbook display developed.
\end{abstract}

Keywords: electronic instructional materials, problem based learning, Dick and Carey model

\section{Pendahuluan}

Peningkatan kualitas pendidikan dapat dilakukan dengan memperbaiki kualitas pembelajaran (Degeng, 2013). Dalam belajar peserta didik selain berinteraksi dengan pendidik sebagai salah satu sumber belajar, peserta didik juga berinteraksi dengan semua sumber belajar yang mungkin dipakai untuk mencapai hasil yang diinginkan (Fry, Ketteridge, \& Marshall, 2014). Selain itu, dalam melaksanakan kompetensi pedagogik, pendidik dituntut memiliki kemampuan secara metodologis dalam hal perancangan dan 
pelaksanaan pembelajaran termasuk di dalamnya penguasaan dalam penggunaan sumber belajar (Reigeluth \& Carr-Cheliman, 2009).

Sumber belajar yang digunakan di pendidikan tinggi khusus Lembaga Pendidik dan Tenaga Pendidikan (LPTK) menjadi hal utama yang perlu disiapkan, dalam rangka peningkatan mutu belajar mandiri pebelajar. Salah satu sumber belajar yang dirasakan belum optimal adalah pada matakuliah strategi pembelajaran. Matakuliah strategi pembelajaran adalah mata kuliah yang masuk dalam mata kuliah penguatan kompetensi pedagogis pendidik. Mata kuliah ini berfungsi dalam membekali mahasiswa secara konseptual dan praktis mengenai belajar dan bagaimana pembelajaran yang seharusnya terjadi.

Sesuai dengan karakteristiknya, matakuliah strategi pembelajaran menitikberatkan pada kemampuan berpikir kritis. Kemampuan berpikir kritis adalah salah satu dari pembelajaran pemahaman konsep. Kemampuan berpikir kritis dan pembelajaran yang menekankan pemahaman konsep adalah tujuan utama dari pembelajaran abad 21 (Jansen \& Merwe, 2015). Untuk itu, sumber belajar perlu disiapkan secara komprehensif untuk menghasilkan sumber belajar yang dibutuhkan untuk mencapai kompetensi abad 21. Kompetensi yang menekankan pada hasil belajar, khususnya pada ranah kognitif pemahaman konsep diperlukan desain pembelajaran dengan pendekatan konstruktivis (Degeng, 2013). Desain pembelajaran untuk pebelajar orang dewasa, menuntut adanya sumber belajar yang dapat mengakomodasi kebutuhan tersebut. Salah satu pendekatan konstruktivis yang efektif dalam meningkatkan hasil belajar adalah pendekatan berbasis problem based learning $(P B L)$. Model PBL sebagai pendekatan pedagogis yang berangkat dari penggunaan kasus dan masalah untuk mencapai tujuan pembelajaran (Birgili, 2015).

Sumber belajar yang dikembangkan adalah bahan ajar yang berupa bahan ajar elektronik. Bahan ajar elektronik dapat mempermudah dalam memasukkan unsur suara dan gambar dinamis seperti video (Dwiyogo, 2013). Selain itu, banyak keunggulan penggunaan buku elekronik terutama dalam hal meningkatkan motivasi belajar (Ciampa, 2012; Jones \& Brown, 2011). Sumber belajar ini menjadi salah satu panduan belajar mahasiswa dalam meningkatkan mutu belajar mandiri. Bahan ajar adalah bahan ajar untuk suatu mata kuliah yang ditulis dan disusun oleh pengajar matakuliah tersebut, mengikuti kaidah tulisan ilmiah dan disebarluaskan kepada peserta kuliah (Dirjen Dikti, 2014). Berdasarkan definisi tersebut, bahan ajar adalah salah satu sumber belajar yang wajib disusun oleh pengajar dan perlu dikembangkan dengan prosedur ilmiah sehingga dapat memenuhi syarat bahan ajar yang dikeluarkan oleh Dikti.

Untuk memenuhi kaidah ilmiah tersebut, maka dilakukan pengembangan bahan ajar matakuliah strategi pembelajaran dengan menggunakan Model Dick \& Carey. Model ini dipilih sebagai dasar pengembangan bahan ajar strategi pembelajaran bagi mahasiswa berdasarkan pertimbangan-pertimbangan sebagai berikut: (1) prosedur kerja Dick \& Carey cukup jelas, (2) model ini mempunyai karakteristik yang mengacu pada tujuan, ada keserasian dengan tujuan, sistematik dan berpedoman pada evaluasi, (3) model rancangan Dick \& Carey menggunakan langkah-langkah yang jelas dalam merancang bahan ajar, (4) model Dick \& Carey menekankan aspek revisi atau perbaikan pembelajaran yang menyeluruh dalam proses pembelajaran, dan (5) model Dick \& Carey dapat digunakan untuk pengembangan bahan pembelajaran pada ranah informasi verbal, ketrampilan intelektual, psikomotor dan sikap yang relevan dengan matakuliah strategi pembelajaran bagi mahasiswa (Dick, Carey, \& Carey (2009).

Berdasarkan latar belakang tersebut di atas maka rumusan masalah yang diajukan dalam penelitian ini adalah sebagai berikut. (i) Apakah dapat dihasilkan bahan ajar elektronik matakuliah strategi pembelajaran berbasis problem based learning dengan menggunakan model Dick and Carey yang sesuai dengan karakteristik mahasiswa? (ii) Bagaimanakah kualitas hasil uji coba produk pengembangan bahan ajar elektronik matakuliah strategi pembelajaran berbasis problem based learning dengan menggunakan model Dick and Carey?

\section{Metode Penelitian}

Penelitian ini dilakukan di Kabupaten Ngada Provinsi Nusa Tenggara Timur. Subjek dalam penelitian ini adalah kurikulum matakuliah strategi pembelajaran serta pakar dan mahasiswa di STKIP Citra Bakti. Sedangkan objek yang diteliti adalah bahan ajar elektronik matakuliah strategi pembelajaran berbasis model problem based learning.

Model pengembangan yang digunakan dalam pengembangan modul pembelajaran matakuliah strategi pembelajaran ini adalah model Dick \& Carey. Model ini terdiri atas 10 langkah, yaitu: (1) mengidentifikasi tujuan instruksional umum, (2) melakukan analisis pembelajaran, (3) mengidentifikasi prilaku dan karakteristik awal pebelajar, (4) merumuskan tujuan pembelajaran khusus, (5) mengembangkan item-item tes acuan patokan, (6) mengembangkan strategi pembelajaran, (7) mengembangkan dan menulis 
bahan pembelajaran, (8) mendesain dan melaksanakan evaluasi formatif, (9) merevisi kegiatan pembelajaran. (10) mendesain dan melaksanakan evaluasi sumatif.

\section{Hasil dan Pembahasan \\ Menetapkan matakuliah yang dikembangkan}

Mata kuliah yang ditetapkan untuk dikembangkan adalah matakuliah strategi pembelajaran bagi mahasiswa program studi keguruan. Pertimbangannya adalah belum ada bahan ajar pada matakuliah strategi pembelajaran yang sesuai dengan kebutuhan dan karakteristik mahasiswa, khususnya terkait dengan kasus kasus untuk mahasiswa wilayah NTT.

Mengidentifikasi tujuan pembelajaran, melakukan analisis pembelajaran, mengidentifikasi perilaku awal dan karakteristik pebelajar, menulis tujuan pembelajaran khusus, dan mengembangkan butir-butir tes acuan patokan

Berdasarkan analisis kurikulum, dilakukan identifikasi Tujuan Pembelajaran Umum (TPU). Setelah Tujuan pembelajaran Umum tersebut diidentifikasi, maka langkah selanjutnya adalah melakukan analisis pembelajaran. Masing-masing tujuan umum tersebut dianalisis ordinat dan subordinatnya yang selanjutnya ditampilkan dalam bentuk gambar hubungan antara ordinat dengan subordinat tersebut. Selanjutnya, berdasarkan hasil identifikasi yang dilakukan terhadap perilaku awal dan karakteristik mahasiswa, maka ditulislah tujuan-tujuan yang ingin dicapai dan mengembangkan butir-butir tes acuan patokan.

Standar kompetensi yang teridentifikasi adalah memahami tentang hakekat teori, perencanaan, pelaksanaan, asesmen dan evaluasi yang melandasi pembelajaran serta berbagai strategi pembelajaran yang dapat diturunkan dari prinsip-prinsip belajar mengajar.

Mengembangkan strategi pembelajaran

Pada tahap ketiga yang dilakukan adalah menyusun strategi pembelajaran guna mencapai tujuan pembelajaran yang telah ditetapkan. Kegiatan ini meliputi aktivitas pembelajaran, penyajian informasi dan umpan balik, pengetesan, dan kegiatan tindak lanjut. Dalam hal ini, pengembangan menggunakan model problem based learning.

\section{Penyusunan dan penulisan bahan ajar elektronik matakuliah strategi pembelajaran bagi mahasiswa}

Bahan ajar dikembangkan dengan menggunakan aplikasi flipbook (flipbook maker pro 3.6.5). Bahan ajar tersebut mempunyai komponen isi yang meliputi: (1) rumusan tujuan, (2) judul bab, (3) uraian, (4) tugas atau latihan, (5) daftar rujukan

\section{. Mendesain dan melakukan evaluasi formatif dan merevisi produk pengembangan}

Evaluasi formatif meliputi uji ahli isi, uji ahli desain dan media pembelajaran, uji coba perorangan, uji coba kelompok kecil, dan uji coba lapangan. Hasil uji coba dapat dipaparkan sebagai berikut.

\section{Hasil uji ahli buku ajar elektronik yang dikembangkan}

Penilaian ini melibatkan dua orang dosen ahli dan dua orang dosen pengampu matakuliah. Hasil penilaian Buku Ajar Elektronik ada pada kategori sangat baik. Buku ajar elektronik yang dikembangkan menurut pada ahli ada pada kategori "sangat baik".

\section{Hasil Uji Perorangan Buku Ajar Elektronik yang Dikembangkan}

Bahan ajar ini kemudian diujicobakan secara terbatas melalui kelompok kecil dengan melibatkan 12 mahasiswa STKIP Citra Bakti. Buku ajar elektronik yang dikembangkan berdasarkan tanggapan mahasiswa, ada pada kategori "sangat baik". Aspek yang paling tinggi menurut tanggapan mahasiswa adalah tampilan buku ajar yang dikembangkan.

\section{Pembahasan}

Buku ajar elektronik yang dikembangkan dalam penelitian ini, sudah sesuai dengan definisi yang diberikan oleh ahli dan pemerintah. Buku ajar merupakan seperangkat materi yang disusun secara sistematis baik tertulis maupun tidak sehingga tercipta lingkungan atau suasana yang memungkinkan siswa untuk belajar (Kemdikbud, 2013). Selain itu, Dirjen Dikti (2014) juga menambahkan bahwa buku ajar merupakan informasi, alat dan teks yang diperlukan guru atau instruktur untuk perencanaan dan penelaahan implementasi pembelajaran.

Dalam pengembangan buku ajar, digunakan buku ajar elektronik untuk mempermudah mahasiswa dalam mempelajari materi. Bagian-bagian yang ada dalam buku elektronik memberikan kontribusi terhadap pengembangan membaca awal anak-anak, sikap, dan motivasi untuk membaca teks-teks digital. Studi 
menunjukkan bahwa buku elektronik, aspek motivasi, dan metode pengajaran konstruktivis dapat meningkatkan motivasi membaca di kalangan pembaca awal (Ciampa, 2012).

Buku elektronik yang tersedia melalui dua sumber utama: situs online dan perangkat elektronik pribadi. Pentingnya perangkat tersebut tidak dapat diremehkan. Ada beberapa faktor yang mempengaruhi transisi dari cetak ke format elektronik, salah satunya adalah sumber daya online menyediakan akses cepat ke bahan bacaan pada titik kebutuhan (Jones \& Brown, 2011).

Bahan pengajaran yang menantang, memberikan pilihan pada peserta didik, dan mempromosikan otonomi dan penentuan nasib sendiri dapat memiliki efek yang positif pada motivasi siswa (Wallden \& Makinen, 2013).

Dengan menggunakan pembelajaran berbasis masalah, pebelajar akan memperoleh keterampilan pembelajaran sepanjang hayat yang meliputi kemampuan untuk menemukan dan menggunakan sumber belajar yang tepat (Williams, 2014)

\section{Simpulan}

Dari hasil penelitian dan pembahasan, dapat disimpulkan sebagai berikut. (1) Pengembangan buku ajar elektronik dapat dilakukan pada matakuliah strategi pembelajaran. (2) Terdapat beberapa aktivitas pemecahan masalah dalam kegiatan diskusi dan contoh contoh kasus dalam buku ajar yang telah dikembangkan. (3) Hasil ujicoba menunjukkan bahwa buku ajar elektronik yang dikembangkan telah layak berdasarkan uji perorangan, kelompok, dan uji lapangan. (4) Hasil uji ahli buku ajar elektronik yang dikembangkan dapat diketahui bahwa buku ajar elektronik yang dikembangkan menurut pada ahli ada pada kategori "sangat baik". Sedangkan hasil uji perorangan buku ajar elektronik yang dikembangkan dapat diketahui bahwa buku ajar elektronik yang dikembangkan berdasarkan tanggapan mahasiswa, ada pada kategori "sangat baik".

\section{Daftar Pustaka}

Prastowo, A. 2011. Pengembangan bahan ajar inovatif. Jakarta: Diva Press

Arends, R.I. 2011. Learning to teach $9^{\text {th }}$. New York: McGraw Hill Companies

Barron, L. Preston-Sabin, J. \& Kennedy, D. 2013. Problem-based learning for the pre-service teacher, SRATE Journal, 22 (2), 39-46.

Birgili, B. 2015. Creative and critical thinking skills in problem-based learning environments. Journal of Gifted Education and Creativity, 2(2), 71-80

Ciampa, K. 2012. Reading in the digital age: Using electronic books as a teaching tool for beginning reader, Canadian Journal of Learning and Technology, 38(2), 1-26

Degeng, I N.S. 2013. Ilmu pembelajaran: Klasifikasi variabel untuk pengembangan teori dan penelitian. Bandung: Kalam Hidup dan Aras Media.

Dick, W., Carey, L., \& Carey, J.O. 2009. The systematic design of instruction $7^{\text {th }}$ Ed. United State of America: Pearson Education.

Dirjen Dikti (Direktorat Jenderal Pendidikan Tinggi). 2014. Pedoman operasional penilaian angka kredit kenaikan pangkat/jabatan akademik dosen. Jakarta. Kemdikbud

Dwiyogo, W.D. 2013. Media pembelajaran. Malang: UM Malang.

Fry, H., Ketteridge, S., \& Marshall, S. 2014. A handbook for teaching and learning in higher education: Enhancing academic practice, $4^{\text {th }}$ edition. London: Roudledge

Hamza, M. 2012. Developing training material guide. Swedish: Civil Contingencies Agency

Isman, A. 2011. Instructional design in education: New Model. The Turkish Online Journal of Educational Technology, 10 (1), 136-142

Jansen, C. \& Merwe, P. 2015. Teaching practice in the $21^{\text {st }}$ century: emerging trends, challenges and opportunities. Horizon Research Publishing. [online] melalui http/:eric.gov.ed/EJ1056080

Jones, T. \& Brown, C. 2011. Reading engagement: A comparison between ebooks and traditional print books in an elementary classroom. International Journal of Instruction, 4(2), 5-23.

Kemendikbud. 2013. Penyusunan rencana pelaksanaan pembelajaran. Jakarta: Kepala Badan Pengembangan Sumber Daya Manusia Pendidikan dan Kebudayaan dan Penjaminan Mutu Pendidikan

Lee, W. W. \& Owens, D. L. 2004. Multimedia-based instructional design: Computer-based training, web-based training, distance broadcast training, performance based solution ( $2^{\text {nd }}$ ed). San Francisco: Pfeiffer A Wiley Imprint. 
Molenda, M. \& Januszewski, A. 2008. Educational technology, a definition with comentary. New York: Lawrence Erlbaum Associates.

Reigeluth, C.M. \& Carr-Cheliman, A.A. 2009. Theories for different outcomes of instruction. Dalam C.M. Reigeluth, \& A.A. Carr-Cheliman (Eds.), Instructional-design theories and models: building a common knowledge base, Vol. 3 (pp. 195-197), New York: Routledge

Wallden, S. \& Makinen, E. 2013. Educational data mining and problem-based learning. Informatics in Education, 13(1), 141-156.

Williams, J.M. 2014. Is student knowledge of anatomy affected by a problem based learning approach? A review. Journal of Education and Training Studies, 2(4), 108-113.

Kitao, K \& Kitao S.K. 2016. Selecting and developing teaching/learning material. The Internet TESL Journal. Diterima melalui http/:iteslj.org/Articles/ Kitao-material.html, pada tanggal 5 Mei 2016. 